\title{
Zpráva z muzeologického semináře Muzeum a etika
}

\section{Report from the Museological Seminar "Museum and Ethics"}

Abstract: The Masaryk Museum in Hodonín organises a bi-annual seminar focused on the current issues of museology. In 2019, the topic of the seminar was the role and the importance of ethics in museums. Various aspects of the topic were discussed, many of which were deemed controversial or previously unopened in the Czech community of museum professionals and academics.

\section{Keywords: seminar, museology, ethics, museum}

Muzeum jako instituce má ve společnosti kromě uchovávání a péče o sbírkové předměty i nezanedbatelnou roli uchovávání kulturní paměti prostřednictvím komunikace s návštěvníky. Ve všech svých funkcích a činnostech se tak muzeum potýká nejen s odbornými a praktickými otázkami, ale $\mathrm{v}$ nezanedbatelné míře se musí zabývat i tématy etickými a hodnotovými. Zejména v současném období společenských změn stojí muzea a obecně kulturní instituce před novými úkoly a náročnými volbami.

Právě z těchto důvodů si letošní ročník tradičního muzeologického semináře, pořádaného Masarykovým muzeem v Hodoníně ve spolupráci s Asociací muzeí a galerií ČR, zvolil za téma etiku v muzejní praxi. Ve dnech 27.-28. listopadu 2019 se v centru jihomoravského Hodonína sešli zástupci z řad muzejních pracovníků a odborné veřejnosti z českých zemí i Slovenska se společným cílem poukázat na obecné etické otázky vnitřního i vnějšího působení muzejních institucí, jejich dílčích složek a příbuzných oborů.

Semináŕ byl slavnostně zahájen proslovem Ireny Chovančíkové, ředitelky Masarykova muzea v Hodoníně a předsedkyně Asociace muzeí a galerií ČR, která zdůraznila potřebu intenzivnější diskuze nad etickými a společenskými otázkami v české muzejní obci. Připomněla taky, že hostujícím městem generální konference ICOM v roce 2022 se stane Praha, a právě otázka definice muzea a jeho významu v současné společnosti bude jednou z nejdiskutovanějších otázek fóra.

Tématem prvního bloku příspěvků byly obecné aspekty etiky v muzeu. Přednášející se $\mathrm{v}$ př́spěvcích zabývali zejména každodenním provozem muzejních institucí a jeho konfrontací ve vztahu k etickým kodexům a profesním požadavkům. $\mathrm{V}$ úvodním př́spěvku se dlouholetá muzejní pracovnice a bývalá ředitelka Muzea Těšínska Věra Tomolová věnovala tématu etiky všedního dne v muzejní praxi. Historik František Šebek se blíže věnoval etickému kodexu muzeí a konfrontací tohoto základního muzejního standardu s realitou běžné praxe. U etických standardů zůstal tematicky i Martin Sekera z Národního muzea, který zhodnotil možnosti a potenciální problémy muzejních pracovníků ve vztahu k dodržování standardů etiky odpovědnosti. Oblasti muzejního marketingu byl blízký př́spěvek Michaely Smidové a Petry Štůlové z Centra pro prezentaci kulturního dědictví (Národní muzeum). Ten se věnoval $\mathrm{v}$ českém prostředí velmi málo reflektované oblasti muzejních obchodů a etickým aspektům jejich provozu, koncepce a nabízeného sortimentu. Blok zakončil př́spěvek Stanislavy Gogové a Jarmily Maximové z Katedry muzeologie Filozofické fakulty Univerzity Konštantína Filozofa v Nitře. Slovenské výzkumnice představily svůj projekt

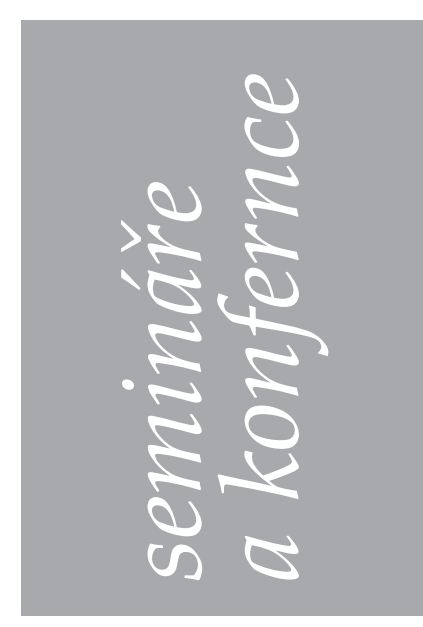

Mgr. Michaela Smidová Centrum pro prezentaci kulturního dědictví Národní muzeum michaela.smidova@nm.cz 
komparativní analýzy vybraných národních (slovenských) a nadnárodních legislativních dokumentů z oblasti muzejnictví. Obě přednášející mimořádně ocenily zvolené téma konference, jelikož v povědomí českých i slovenských muzejníků jsou i přes znalost př́slušných kodexů etické otázky, at' už $\mathrm{v}$ rovině teoretické nebo praktické, i v současnosti do značné míry marginalizovány.

Druhý středeční blok př́íspěvků nesl název Etika jednotlivých muzejních sfér. Po představení etických otázek, před kterými každodenně stojí muzejní instituce a jejich pracovníci, tak dostala slovo i specializovaná oddělení. Ta jsou neoddělitelnou součástí fungování muzeí a galerií, a často stojí před specifickými problémy a dilematy vyplývajícími z jejich zaměření. Pavel Jirásek, nezávislý konzultant kulturních institucí pro oblast ochrany a využívání kulturního dědictví, představil posluchačům etické aspekty zabezpečení sbírek a ochrany muzejního fondu. Obor konzervace a restaurování včetně jeho etických stránek zastupovala vedoucí Metodického centra konzervace Technického muzea v Brně Alena Selucká. Živou diskuzi vzbudil zejména př́spěvek Ondřeje Dostála z oblasti př́rodních věd. Bezpochyby nejdiskutovanější a nejproblematizovanější otázkou, týkající se zejména archeologických a antropologických expozic, se ukázalo být vystavování lidských ostatků. Jak ilustroval přednášející, v muzeích v České republice ani ve světě není toto téma dostatečně reflektováno, a to i přes důraz na úctu k člověku i po jeho smrti v téměř všech světových kulturách.

Předmětem třetího konferenčního bloku, který zároveň uzavřel konferenci, byla Etika a prístup ke sbírkám. Mezi přednášejícími $\mathrm{v}$ tomto bloku dominovali kurátoři z městských nebo oblastních muzeí se svými př́padovými studiemi. Výjimkou byl první př́spěvek Balázse Komoróczyho z Archeologického ústavu AV ČR a Petra Fedora reprezentujícího Odbor kultury a památkové péče Jihomoravského kraje. Ve své prezentaci představili aktuální téma detektorového hledání archeologických nálezů a možné řešení praktických problémů $\mathrm{v}$ této oblasti na př́kladu spolupráce amatérských archeologů a muzejních institucí předmětného kraje. Jakub Smrčka z Husitského muzea v Táboře se ve svém prríspěvku věnoval oblasti, která v muzejnictví nepatří ke standardním předmětům zájmu, a to teologické etice. Po základním vymezení pojmu a průřezu vymezenými oblastmi oboru teologické, specificky křestanské, etiky se přednášjící pokusil najít možnosti její aplikace ve tvorbě a péči o muzejní sbírky. Ondřej Machálek se naopak vyjádřil k tématu, které se dlouhodobě těší značné pozornosti široké veřejnosti, a to prezentace řemesel v muzeích. I pres dlouholetou tradici a vysokou návštěvnickou popularitu tohoto typu muzejních aktivit jsou v praxi nezrrídka opomíjeny některé jejich etické aspekty. Zdůraznil především nezbytnost uchovávání původních řemeslných postupů jako významné součásti nehmotného kulturního dědictví. Jitka Šrejberová na př́kladu objekti̊ z provenience svého pracoviště, Oblastního muzea a galerie v Mostě, ilustrovala rozporuplné stránky ochrany a péče o sbírkové předměty uměleckého charakteru. Konferenční blok, stejně jako konferenci samotnou, uzavřel př́spěvek Petra Chlebce, kurátora Městského muzea v Blatné, který polemizoval na téma konstrukce obrazu regionálních dějin v lokálních a regionálních muzeí. $V$ přispěvku se zaměřil mimo jiné i na roli paměti a nových konceptů v oboru pamětových studií u formování této konstrukce.

V závěru je možné říct, že seminář byl př́inosný zejména $\mathrm{v}$ samotném představení tématu, které je v literatuře i výzkumu často upozaděno. Jak ale prokázaly příspěvky účastníků z různých oblastí muzejní praxe, etické otázky jsou přítomny v každodenním provozu muzejních institucí a je nevyhnutelné se jimi zaobírat. Z vysoké kvality prezentací, aktivní a odborné diskuze je zřejmé, že o toto téma je i v českém prostředí zájem. Ten bude nepochybně ještě podnícen připravovanou kolektivní monografií ze semináře. 